\title{
Brunetto Latini, Le Livre du Trésor, Livre I
}

\section{G. Matteo Roccati}

\section{(2) OpenEdition}

\section{Journals}

\section{Édition électronique}

URL : http://journals.openedition.org/studifrancesi/4298

DOI : 10.4000/studifrancesi.4298

ISSN : 2427-5856

\section{Éditeur}

Rosenberg \& Sellier

\section{Édition imprimée}

Date de publication : 1 septembre 2016

Pagination : 302

ISSN : 0039-2944

\section{Référence électronique}

G. Matteo Roccati, «Brunetto Latini, Le Livre du Trésor, Livre I », Studi Francesi [En ligne], 179 (LX | II) |

2016, mis en ligne le 01 septembre 2016, consulté le 18 septembre 2020. URL : http://

journals.openedition.org/studifrancesi/4298; DOI : https://doi.org/10.4000/studifrancesi.4298

Ce document a été généré automatiquement le 18 septembre 2020.

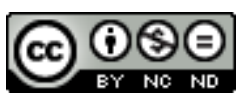

Studi Francesi è distribuita con Licenza Creative Commons Attribuzione - Non commerciale - Non opere derivate 4.0 Internazionale. 


\title{
Brunetto Latini, Le Livre du Trésor, Livre I
}

\author{
G. Matteo Roccati
}

\section{RÉFÉRENCE}

BRUNETTO LATINI, Le Livre du Trésor, Livre I, Traduction en français moderne, introduction, notes par Bernard Ribémont et Silvère Menegaldo, Paris, Honoré Champion, 2013, «Traductions des classiques du Moyen Âge» 94, XCII-490 pp.

1 L'introduction présente l'auteur et son œuvre-Rettorica, Tesoretto, Favolello, Trésor-, avec une attention spéciale pour le premier livre de ce dernier: la classification des sciences qui se trouve en ouverture du livre, la nature particulière de celui-ci - le livre I est encyclopédique alors que les deux autres s'apparentent plutôt à un traité de bon gouvernement-, la forme d'exposition et la méthode de compilation, enfin le destinataire; la bibliographie (pp. LxIX-Xc) fait suite. La traduction, assez libre, de manière à la rendre agréable à la lecture, a été établie à partir de l'édition Carmody (1947), vérifiée systématiquement sur l'édition Beltrami (2007), «en choisissant toujours la leçon qui nous paraissait la meilleure» (p. LXvI). Les notes en bas de page ont été conçues "pour expliquer des notions diverses à caractère scientifique, pour expliciter les sources de Latini et, au-delà, pour donner différentes pistes de travail sur les traditions qui ont pu aboutir aux sources de l'encyclopédiste» (p. LXVII). Terminent le volume la table des chapitres et l'index (pp. 469-487). 